\title{
POLITIK HUKUM JUDICIAL REVIEW DI INDONESIA
}

\author{
Kartono \\ Fakultas Hukum Universitas Jenderal Soedirman Purwokerto \\ E-mail: kartonogs@ymail.com
}

\begin{abstract}
Although Indonesia judicial review system is not opens the possibility of regulations review under the act against the constitution, das sollen pracitically these conditions may still occur. From political of law the legal authority of constitutional court should be able to put the interests of citizens rights that are based on the principles of recognition, guarantees, protection and legal certainty of a fair and equal treatment before the law. Given that changes in the constitution can not be done easily, then the judicial review in UUD 1945 should not be formulated too limitedly that restricting the organic law to complete and explore the authority that is adaptable to any concrete problem.
\end{abstract}

Keywords: politics of law, constitutional court, UUD 1945, limitedly.

\begin{abstract}
Abstrak
Meskipun secara das sein sistem judicial review Indonesia tidak membuka kemungkinan pengujian peraturan perundang-undangan di bawah undang-undang terhadap konstitusi, das sollen kondisi tersebut bisa saja terjadi dalam praktik. Karena itu dari sisi politik hukum kewenangan Mahkamah Konsitusi harus mampu diletakan pada kepentingan hak asasi warga negara yang berlandaskan pada asas pengakuan, jaminan, perlindungan, dan kepastian hukum yang adil serta perlakuan sama di depan hukum. Mengingat bahwa perubahan UUD tidak dapat dilakukan secara mudah, maka judicial review dalam UUD 1945 hendaknya tidak dirumuskan terlalu limitatif yang membatasi undang-undang organik untuk melengkapi dan mengeksplorasi kewenangan yang bersifat antisipatif terhadap persoalan konkrit.
\end{abstract}

Kata Kunci: politik hukum, mahkamah konstitusi, UUD 1945, limitatif.

\section{Pendahuluan}

Pembentukan lembaga hukum tanpa dibarengi visi dan konsepsi menyeluruh dalam penegakan hukum memberikan peluang negatif dalam pembangunan hukum itu sendiri. Dalam upayanya membangun kerangka negara hukum, terben-tuknya visi baru hasil amandemen UUD menun-tut pemahaman dan kebijakanaaan yang berlan-daskan prinsip negara hukum. Formulasi pikir ini menghendaki agar pembangunan hukum di Indonesia paling tidak menyiratkan dua hal. Pertama, hukum diharapkan berfungsi sebagai landasan kehidupan bernegara. Kedua, dengan hukum dapat berfungsi maka pembangunan hukum pun lebih mudah direalisasikan. Namun pembentukan lembaga hukum baru acapkali tidak sejalan dengan harapan. Pemicunya antara lain tidak masuknya pertimbangan politik hukum dalam pembentukan lembaga yang ada.

Mahkamah Konstitusi (MK) terbentuk karena implementasi paham konstitusionalisme. Paham yang menghendaki pembatasan kekuasaan. MK mendapat amanah untuk menyelesaikan problem hukum yang relevan dengan konstitusi kenegaraan dan diharapkan memberi koreksi atas praktik pradilan yang terjadi sebelumnya, yang dalam perjalanan waktu lebih dari tiga dasawarsa terbukti jika "kekuasaan kehakiman yang merdeka" ternyata tidak sepenuhnya dilaksanakan dengan baik. Banyak indikasi penyimpangan dari berbagai perundangan di bidang peradilan. ${ }^{1}$

Hadi Supriyanto, "Pemisahan Fungsi Kekuasaan Eksekutif dan yudikatif", Jurnal Legislasi Indonesia, Volume 1 Nomor 1 Juli 2004, hlm. 1 
Salah satu esensi utama paham konstitusionalisme adalah konsep perlindungan hakhak sipil warganegara. ${ }^{2}$ Kebebasan warga-negara dijamin oleh konstitusi. Kekuasaan negara pun dibatasi konstitusi, dan kekuasaan itu hanya memperoleh legitimasinya dari konstitusi. ${ }^{3}$ Formulasi ini mengindikasi dianutnya gagasan supremasi konstitusi (supremacy of constitution) di Indonesia. Bukan supremasi parlemen (supremacy of parliament). Dalam alur pikir grundnorm theory dari Kelsen maka segala peraturan yang berada di bawah konstitusi tidak boleh bertentangan dengan konstitusi. Kepentingan atau motif politik tidak boleh bertabrakan dengan norma konstitusi (constitutional norms). Konstitusi sebagai hukum tertinggi negara (the supreme law of the land) tidak boleh disimpangi peraturan perundang-undangan di bawahnya.

Pengujian konstitusionalitas kewenangan MK dalam UUD 1945 dibatasi hanya pada pengujian undang-undangan terhadap UUD. Oleh karena itu, secara konstitusional peraturan perundang-undangan di bawah UU tidak dilogikakan bertentangan dengan konstitusi. Peraturan perundangan-undangan di bawah undang-undang hanya logis bertentangan dengan undangundang atau peraturan perundang-undangan di atasnya. Tidak dengan konstititusi. Politik hukum negara telah mengakomodasi sistem ini melalui prosedur hak uji materiil yang menjadi kompetensi Mahkamah Agung.

Das sein sistem judicial review Indonesia yang tidak membuka kemungkinan pengujian peraturan di bawah UU terhadap konstitusi dianggap sebagai kelemahan. Das sollen sangat mungkin terjadi peraturan di bawah undang-undang ternyata melanggar hak konstitusional (constitutional rights violation) warga negara.

Lihat Imam Alfiannor, "Konsep Hak Asasi Manusia dan Implikasi Penegakkannya di Indonesia", Syariah: Jurnal Ilmu Hukum, Vol. 8 No. 1, Juni 2008, hlm. 112-115; Albert Hasibuan, "Politik Hak Asasi Manusia (HAM) dan UUD 1945”, Law Review Vo. VIII No. 1, Juli 2008, hlm. 46-52; Lihat Sudi Fahmi, "Menuju Keseimbangan Hubungan antar Legislatif dan eksekutif", Jurnal Hukum Respublica Vol. 2 No. 4, Tahun 2003, hlm. 211

3 Soetandyo Wignjosoebroto, 2003, Hukum, Paradigma, Metode dan Masalahnya, Jakarta: Elsam-Huma, hlm. 405
Meskipun secara substansial tidak bertentangan dengan peraturan di atasnya.

Pengujian konstitusional hanya terhadap UU (formal) tanpa kemungkinan pengujian peraturan perundang-undangan di bawah UU terhadap konstitusi dapat terjadi, jika sistem norma berjenjang peraturan perundangun-dangan bersifat tertutup. Hal ini berarti produk peraturan di bawah UU hanya merupakan pelaksanaan dari undang-undang atau peraturan di atasnya, maka pengujian dapat dilakukan secara langsung terhadap peraturan di atasnya. Kenyataannya sistem penormaan tertutup hanya berhenti di tingkat peraturan pemerintah saja. Ini karena eksistensi peraturan pemerintah yang hanya berfungsi menjalankan undang-undang sebagaimana mestinya, sehingga tidak ada peraturan pemerintah tanpa undang-undang terlebih dahulu. Formulasi ini menunjukkan bahwa peraturan pemerintah hanya dapat diuji secara materiil terhadap UU saja.

Berbeda halnya yang terjadi pada peraturan daerah (perda). Kendatipun perda merupakan jabaran yuridis dari peraturan yang lebih tinggi, pengujian perda ternyata tidak hanya peraturan yang lebih tinggi, tetapi juga tidak boleh bertentangan dengan kepentingan umum. Formulasi larangan bertentangan dengan kepentingan umum esensinya membuka peluang terbukanya substansi perda berbeda dengan apa yang belum dirumuskan dalam peraturan yang lebih tinggi. Kondisi riil ini dapat diilus-trasi terhadap munculnya tendensi perda pela-curan. Sampai saat ini belum ada satupun UU yang melarang praktek pelacuran di Indonesia. Das sein seorang pelacur yang diadili dengan alasan perbuatannya bertentangan dengan per-da, dalam sidang yang bersangkutan dapat mengajukan dalil bahwa perda itu bertentangan dengan Pasal 28A konstitusi. Pasal ini menjamin bahwa setiap orang berhak untuk hidup serta berhak mempertahankan hidup dan kehidupannya.

Sistem konstitusionalisme di Indonesia yang mendasari terbentuknya berbagai peraturan dibawahnya, selayaknya dapat berfungsi sebagai aturan dasar dalam kehidupan bernegara. Kenyataan, bahwa konstitusi dan UU orga- 
niknya menimbulkan ketidakpastian dan kekosongan hukum telah menciptakan kesulitan penegakan hukum di Indonesia.

Hukum adalah sebuah entitas yang sangat kompleks, meliputi kenyataan kemasyarakatan yang majemuk, meliputi banyak aspek, dimensi dan fase. ${ }^{4}$ Pembentukan hukum melalui UU bertujuan untuk pemositifan perlindungan hak asasi manusia yang menjadi esensi negara hukum. Perlindungan ini tentu mensyaratkan mekanisme kontrol sebagai bagian dari kepentingan hukum masyarakat. Baik kontrol sosial, kontrol yuridis maupun kontrol politik. ${ }^{5}$ Melalui hukum, kepentingan ini diintegrasikan agar perlindungan hak-hak subyektif masyarakat tidak dikurangi. Kepentingan hukum dilakukan dengan memberi akses seluas-luasnya bagi masyarakat dalam mencari keadilan. Hukum melindungi kepentingan masyarakat dengan mengalokasikan kekuasaan kepada hukum itu sendiri untuk bertindak dalam kepentingannya tersebut. Alokasi kekuasaan ini dilakukan secara terukur. Ditentukan keluasan dan kedalamannya. Kekuasaan itulah yang disebut hak. Dengan demikian, tidak setiap kekuasaan dalam masyarakat bisa disebut sebagai hak. Hanya kekuasaan tertentu saja yang diberikan hukum kepada seseorang atau lembaga penegak hukum.

Berpijak dari pemikiran di atas, adalah keharusan bagi negara pada saat merumuskan ketentuan dalam peraturan perundang-undangan harus senantiasa memperhatikan aspek kepastian hukum dan perlindungan hak warganegara. Oleh karena itu, untuk mencapainya diperlukan analisis politik hukum menyeluruh terhadap persoalan judicial review. Analisis politik hukum memegang peranan yang penting. Melalui pendekatan ini hukum yang dibentuk setidaknya akan lebih banyak mempertimbangkan keseluruhan kepentingan warganegara sebagai pencari keadilan.

\footnotetext{
4 Yahya, "Perancangan Undang-undang Sebagai Suatu Sintesis Politik dan Hukum", ljtihad: Jurnal Wacana Hukum Islam dan Kemanusiaan, Vol. 8 No. 1, Juni 2008, hlm. 93

5 Artidjo Alkostar, "Prospek Hak Asasi Manusia Abad XXI", Jurnal Inovasi, Universitas Muhammadiyah Yogyakarta No. 1 Tahun IX/2009, hal. 27
}

\section{Pembahasan \\ Konsep Teoritis}

Istilah politik hukum, secara etimologis berasal dari istilah Belanda Rechtspolitiek. Istilah ini merupakan bentukan dari kata rechts dan politiek. Dalam bahasa Indonesia rechts berarti hukum, dan politiek mengandung arti beleid atau kebijakan. Berdasarkan penjelasan tersebut politik hukum secara singkat diartikan sebagai kebijakan hukum. Kebijakan berarti rangkaian konsep dan asas yang menjadi garis besar dan dasar rencana dalam pelaksanaan suatu pekerjaan, kepemimpinan, dan cara bertindak. Politik hukum secara umum dapat dirumuskan sebagai rangkaian konsep dan asas yang menjadi garis besar dan dasar rencana dalam pelaksanaan suatu pekerjaan, kepemimpinan, dan cara bertindak dalam bidang hukum. Politik hukum adalah kebijakan penyelenggara negara tentang apa yang dijadikan kriteria untuk menghukumkan sesuatu. Kebijakan ini dapat berkaitan dengan pembentukan hukum, penerapan hukum, atau penegakan hukum itu sendiri. $^{6}$

Salah satu arah politik hukum nasional yang dicanangkan Indonesia setelah agenda perubahan konstitusi (constitutional reform) adalah melanjutkan agenda pembentukan dan perubahan hukum (legal reform). Bidang hukum yang memerlukan pembentukan dan pembaruan tersebut dikelompokkan menurut bidang-bidang yang dibutuhkan. Bidang ini meliputi: pertama, politik dan pemerintahan; kedua, ekonomi dan dunia usaha; ketiga, kesejahteraan sosial dan budaya, dan keempat, penataan sistem dan aparatur. ${ }^{7}$ Dengan pijakan ini maka bentuk hukum yang perlu disusun dan diperbarui tidak saja berupa UU tetapi juga peraturan pemerintah, peraturan presiden, peraturan menteri dan peraturan di lingkungan lembaga-lembaga ting-

Eddy Asnawi, "Relevansi Politik Hukum dan Strategi Pembangunan Hukum Dalam Rangka Menuju Sistem Hukum Nasional", Jurnal Hukum Respublika Vol. 3 No. 1, Tahun 2003, hlm. 98

7 Jimly Ashiddiqie, 2006, Pembangunan Hukum dan Penegakan Hukum Di Indonesia, Makalah, Lustrum XI FH UGM, 17 Februari 2006, hlm. 5; lihat juga Imam Syaukani, "Kareakteristik Politik Hukum Nasional", Harmoni: Jurnal Multikultural Multireligius Vol. 7 No. 8 Tahun 2008 
gi negara dan badan khusus independen lainnya seperti; Mahkamah Agung, Mahkamah Konstitusi, Bank Indonesia, Komisi Pemilihan Umum dan sebagainya. Termasuk lembaga-lembaga di daerah.

Konsep judicial review di Indonesia banyak berkembang setelah amandemen UUD 1945. Terutama dengan dibentuknya MK. Mulai dari istilah yang mengundang berbagai perdebatan. Seperti istilah judicial review, toetsingrecht, constitutional review, yang seringkali tumpang-tindih satu dengan lainnya. Berbeda cakupan maknanya daripada istilah constitutional review. Judicial Review dalam sistem common law tidak hanya bermakna 'the power of the court to declare laws unconstitutional'. Namun demikian, istilah tersebut juga berkaitan dengan kegiatan examination of administration decisions by the court. ${ }^{8}$ Konsep judicial review hadir dalam objek yang lebih luas jika dibandingkan dengan konsep constitutional review yang hanya sebatas pengujian konstitusional suatu aturan hukum terhadap konstitusi (UUD).

Objek judicial review bisa menyangkut legalitas peraturan di bawah UU terhadap UU. Tidak hanya sekedar UU terhadap konstitusi saja. Dari subjek pengujinya makna judicial review juga mengalami penyempitan. Judicial review hanya dapat dilakukan melalui mekanisme peradilan (judiciary) yang dilaksanakan hakim. Sedangkan, constitutional review subjek pengujinya dapat dilakukan pengadilan (judicial review), lembaga legislative (legislative review), lembaga eksekutif (executive review) atau bahkan lembaga lain yang ditunjuk untuk melaksanakan fungsi tersebut. Pemberian hak uji inilah yang menjadi pengertian dari 'toetsingsrecht'. Judicial review hanya berlaku jika pengujian dilakukan terhadap norma hukum yang bersifat abstrak dan umum (general and abstract norms) secara 'a posterior'. Hal ini berarti bahwa norma hukum tersebut telah diundangkan oleh pembentuk UU.

8 Clapp, James E., 1996, Random House Webster's Pocket Legal Dictionary, New York: Random House Reference, hlm. 232.
Objek judicial review dalam praktek dikenal tiga macam norma yang bisa diuji. Pertama, adalah keputusan normatif yang berisi dan bersifat pengaturan (regeling). Kedua, adalah keputusan normatif yang berisi dan bersifat penetapan administratif (beschikking). Ketiga, keputusan normatif yang berisi dan bersifat penghakiman (judgement/vonnis).

Menurut ahli hukum, cakupan pengujian judicial review oleh badan peradilan meliputi peradilan tata negara di MK (constitutional adjudication), peradilan tata usaha negara (PTUN) di MA (administrative adjudication) mau pun badan peradilan tata usaha negara yang ada di bawah MA. Namun demikian, pengertian luas tersebut umumnya dipersempit dengan tidak mengikutsertakan PTUN yang berada di bawah lingkungan MA. Maka pengertian peradi-lan judicial review yang dimaksud dimaknai sebagai fungsi MK dan fungsi tertentu dari MA. Dalam pembahasan ini ruang lingkup judicial review akan mengikuti makna di atas. Yaitu makna yang lebih luas, khusunya fungsi badan peradilan dari MK yang diatur dalam Pasal 24 C UUD 1945 dan UU No. 24 Tahun 2003 tentang Mahkamah Konstitusi.

\section{Perkembangan Judicial Review di Indonesia}

Istilah judicial review merupakan istilah teknis khas hukum tata negara Amerika Serikat yang merujuk pada wewenang pengadilan untuk membatalkan setiap perbuatan pemerintahan yang bertentangan dengan konstitusi. Istilah ini pertama kali digunakan dalam kasus "Marbury vs Madison" pada tahun $1803 .{ }^{9}$ Majelis Hakim

\footnotetext{
Kasus ini dimulai dari peristiwa pengangkatan sekelompok hakim baru di larut malam (the midnight judges) oleh presiden lama John Adams menjelang serah terima jabatan kepada presiden terpilih Thomas Jefferson. Pengangkatan itu memicu kemarahan seorang hakim baru, William Marbury yang merasa keberatan tatkala surat pengangkatannya selaku hakim tidak diberikan oleh Secretary of State, James Madison berdasarkan perintah Presiden Thomas Jefferson. Pemerintah bermaksud membatalkan pengangkatan hakim-hakim baru di malam yang larut itu. William Marbury memohon kepada Supreme Court agar mengeluarkan Write of Mandamus guna memerintahkan Secretary of State, James Madison menyerahkan surat pengangkatan dirinya. Berdasarkan Judiciary Act 1789, perkara yang diajukan Marbury termasuk original jurisdiction dari Supreme Court sehingga tidak perlu melalui pengadilan yang lebih rendah.
} 
Agung di bawah Chief Justice John Marshall memutus perkara dimaksud dengan cara peng-ujian materil undang-undang. Yakni, mengada-kan judicial review terhadap UU yang dipan-dang bertentangan dengan konstitusi. Sejak putusan itu dunia peradilan Amerika dibekali kewenangan judicial review terhadap UU. Termasuk bagi perkara individual.

Belanda - dalam sejarahnya - sebagai penganut paham eropa kontinental menolak konsep constitutional review. Belanda cenderung mengedepankan upaya administrasi melalui lembaga peradilan administrasi (administrative court). Namun demikian di Belanda juga dikenal istilah hak menguji (toetsingsrecht). Walau pun antara toetsingsrecht dengan judicial review memiliki pengertian dasar yang berbeda, kedua mekanisme ini memiliki substansi tujuan yang sama, yakni perlindungan terhadap hak konstitusional warga negara dan penghargaan ter-hadap konstitusi sebagai norma dasar.

Ditolaknya konsep judicial review di Belanda berakibat ajaran ini awalnya juga tidak begitu berkembang di Indonesia. Para pemikir hukum Indonesia sejak awal lebih mengenal prinsip hukum Eropa Kontinental yang menjunjung civil law. Maka sistem hukum peradilan Indonesia di bawah UUD 1945 tidak mengikuti jejak peradilan Amerika Serikat. Pasal 26 ayat (1) Undang-undang Nomor 14 Tahun 1970 tentang Pokok-Pokok Kekuasaan Kehakiman hanya memberikan kewenangan MA untuk menyatakan tidak sah semua peraturan dari tingkat yang lebih rendah dari UU atas alasan bertentangan dengan peraturan yang lebih tinggi. Kewenangan serupa juga dinyatakan pula dalam Pasal 31 ayat (1) dan (2) UU No. 14/1985 tentang Mahkamah Agung. Terakhir UU No. 4/2004 tentang Kekuasaan Kehakiman (Pasal 11 ayat (2) huruf b) dan UU No. 5/2004 (Pasal 31 ayat (1)). MA hanya mem-punyai kewenangan menguji secara materil hanya terhadap peraturan di bawah UU.

Tahun 1999 reformasi hukum di Indonesia menyepakati terbentuknya pengujian konstitusional. Pertama kali dalam sistem kenegaraan Indonesia terbentuk lembaga yang berwenang menguji UU terhadap UUD serta berfungsi sebagai penafsir UUD. Pada mulanya kewenangan ini diberikan kepada MPR sambil menunggu terbentuknya MK (constitutional court). Ketentuan ini diatur dalam Pasal 5 ayat (1) Tap MPR No. III/MPR/2000. Ketetapan ini muncul sebagai akibat tekanan demokrasi dan tuntutan reformasi.

Satu hal penting hasil amandemen UUD 1945 adalah lahirnya MK sebagai lembaga yang berwenang untuk melakukan pengujian materiil. Masuknya MK dalam pengaturan konstitusi tidak lepas dari kelemahan UUD yang dianggap tidak mencukupi dan tidak memadai untuk menyelesaikan persoalan yang muncul dalam praktik kenegaraan. Prinsip kenegaraan dalam UUD tidak menyiapkan mekanisme check and balances yang seimbang antar cabang kekuasaan yang dibentuk. Akan tetapi menumpuk di satu cabang kekuasaan sehingga menimbulkan ke-kuasaan sentralistik dan otoriter.

Gagasan pembentukan MK tidak lain timbul dari dorongan dalam penyelenggaraan kekuasaan dan keegaraan yang lebih baik. Keberadaan MK dalam sistem kenegaraan Indonesia setidaknya banyak memberi peran bagi penguatan hak-hak konstitusional warga negara. Lebih dari itu keberadaannya juga sekaligus mengawal pelaksanaan UUD 1945 secara murni dan konse-kuen, tidak sekedar slogan seperti masa orde baru. Meskipun beberapa putusannya menuai banyak kontroversi. ${ }^{10}$ Keberadaan MK patut diapresiasi sebagai upaya memberi perlindungan dan jaminan hak konstitusional warga negara.

Sejak dibentuk pada 13 Agustus 2003, MK setidaknya telah mengadili 384 perkara. Perinciannya mencakup 228 perkara pengujian UU

\footnotetext{
Di antara putusan Mahkamah Konstitusi yang menimbulkan kontroversi adalah berkait dengan kewenangan Komisi Yudisial (KY). Putusan ini mengurangi kewenangan KY dalam hal pengawasan terhadap perilaku hakim. Dalam putusannya MK berpendapat, pasal-pasal dalam UU KY yang mengatur fungsi pengawasan terbukti menimbulkan ketidakpastian hukum. Adalah pasal 13 huruf b junto pasal 20 UU KY mengenai wewenang lain sebagai penjabaran pasal 24B ayat 1 UUD 1945 yang dinilai menggunakan rumusan kalimat berbeda sehingga menimbulkan ketidakpastian hukum atau rechtzeker-heid. Menurut MK, undang-undang KY terbukti tidak rinci mengatur mengenai prosedur pengawasan,tidak jelas dan tegas menentukan subjek yang mengawasi, apa objek yang diawasi, instrumen apa yang digunakan serta bagaimana proses pengawasannya dilaksanakan.
} 
terhadap UUD (revewing laws against the constitution). 11 perkara sengketa kewenangan lembaga negara (dispute over the authorities of state institutions) dan perselisihan hasil pemilihan umum (disputes of the general election results) sejumlah 45 perkara Pemilu 2004 dan 71 perkara Pemilu 2009. Juga 27 perkara perselisihan hasil pemilihan umum kepala daerah (disputes of the head regional election results). MK juga menerima permohonan sengketa pemilihan presiden dan wakil presiden pada tahun 2004 dan 2009 dengan masing-masing satu perkara.

\section{Politik Hukum Judicial Review Indonesia}

Persoalan substansial menyangkut pengujian konstitusional (judicial review) peraturan di bawah UU terhadap UUD terutama berpijak pada teori Kelsen. Dalam pendekatan stufenbau des recht yang diajarkan Kelsen, hukum positif dikonstruksi berjenjang dan berlapislapis. Peraturan yang rendah bersumber dari dan tidak boleh bertentangan dengan peraturan yang lebih tinggi. Teori ini dalam ilmu hukum kemudian melahirkan asas hukum lex superior derogat legis inferiori. Semua peraturan yang bertentangan dengan konstitusi harus dinyatakan tidak berlaku.

Uji konstitusionalitas peraturan di bawah UU terha-dap UUD beberapa ahli bertumpu pada hirarki penyusunan peraturan secara berjenjang. Pengakuan hirarki ini dimulai saat disusun draft rancangan peraturan. UU disusun dengan merujuk kepada UUD. Peraturan Pemerintah (PP) merujuk kepada UU, karena peraturan pemerintah disusun untuk melaksanakan UU. Maka peraturan pemerintah tidak langsung merujuk kepada UUD. Konsekuensinya pengujian PP hanya dilakukan terhadap UU yang wewenangnya ada pada MA. Pengakuan hirarki inilah yang tidak memungkinkan pengujian materil peraturan di bawah UU langsung kepada UUD.

Pemikiran di atas bertumpu pada alur pikir seolah pembentukan peraturan di bawah UU bersifat tertutup. Hal ini berarti, tidak mungkin terbentuk peraturan di bawah UU jika UU formilnya belum ada. Kenyataannya terdapat berbagai peraturan di bawah UU yang substansi-nya tidak atau belum diatur UU atau peraturan lain di atasnya. ${ }^{11}$ Dari sisi hukum ini menimbul-kan persoalan karena dapat dianggap mem-batasi hak asasi pencari keadilan. Das sein, se-luruh peraturan perundang-undangan, mulai dari UU hingga perda secara teoritik dapat bertentangan secara konstitusional terhadap UUD secara langsung. Dalam peraturan perun-dangundangan sangat mungkin terjadi kondisi tidak ada penyimpangan substansi terhadap peraturan diatasnya, tetapi melanggar hak konstitusional warga negara. Tatkala pembentuk UU merumuskan peraturan harus senantiasa memperhatikan aspek kepentingan hukum pencari keadilan. Untuk mencapai hal ini faktor politik hukum sangat menentukan. Bagi beberapa negara pola pikir ini menjadi sarana yang efektif. Tetapi di Indonesia, politik hukum yang demikian belum dapat ditemukan. Keberadaan peraturan masih sebatas ketentuan normatif yang kering semangatnya dalam melindungi hak asasi warganegara dalam mengakses keadilan.

Analisis peran politik hukum dalam persoalan judicial review memegang peranan penting. Melalui pendekatan ini hukum yang dibentuk setidaknya harus lebih banyak memperhatikan asas kepastian dan keadilan. ${ }^{12}$ Konstruksi ini merujuk Pasal 1 ayat (3) UUD 1945 bahwa Negara Indonesia adalah negara hukum. Eksplisit dipesankan bahwa hal itu ditujukan agar sistem pemerintahan negara diselenggarakan atas hukum dan bukan atas kekuasaan belaka. The founding fathers menyampaikan makna tersebut dalam rumusan tujuan negara dan da-

11 Dalam Perda Kota Tangerang No. 8 Tahun 2005 tentang Pelarangan Pelacuran pertimbangan yuridisnya mencakup: (1) UU Nomor 6 Tahun 1974 tentang Ketentuanketentuan Pokok Kesejahteraan Sosial, (2) UU Nomor 8 Tahun 1981 tentang KUHAP, (3) UU Nomor 2 Tahun 1993 tentang Pembentukan Kotamadya Tangerang, (4) UU Nomor 10 Tahun 2004 tentang Pembentukan Peraturan Perundang-undangan, (5) Undang-undang Nomor 32 Tahun 2004 tentang Pemerintahan Daerah, (6) PP Nomor 27 Tahun 1983 tentang pelaksanaan KUHAP, (7) PP Nomor 25 Tahun 2000 tentang Kewenangan Pemerintah dan Kewenangan Propinsi Sebagai Daerah Otonom. Dari peraturan yang dikutip tersebut tidak ada satupun ketentuan yang secara substansial mengatur tentang pelacuran.

12 Sesuai dengan konstruksi hukum yang ditentukan dalam Pasal 28D UUD 1945 sendiri yang menyatakan: "Setiap orang berhak atas pengakuan, jaminan, perlindungan, dan kepastian hukum yang adil serta perlakuan hukum yang sama di hadapan hukum". 
sar negara yang meliputi melindungi segenap bangsa Indonesia dan seluruh tumpah darah Indonesia, memajukan kesejahteraan umum, mencerdaskan kehidupan bangsa, dan ikut serta melaksanakan ketertiban dunia berdasarkan kemerdekaan, perdamaian abadi dan keadilan sosial.

Perlindungan terhadap segenap bangsa Indonesia jelas tertuju pada perlindungan hak asasi. Termasuk perlindungan hak warganegara atas kepastian. Konstruksi pikir ini jika dikaitkan dengan sistem pemerintahan negara yang berdasarkan atas hukum, secara normatif memperlihatkan persoalan tentang hak yang ketentuan hukumnya tidak atau belum diatur dalam UU yang berimplikasi pada pembatasan.

Persoalan pengujian peraturan dibawah UU terhadap UUD terbuka bagi hakim untuk menyelesaikannya. Hakim dalam hal ini diberi wewenang memutus perkara dalam hal tata hukum tidak memuat norma umum. Hakim dapat menambahkan hukum suatu norma khusus yang terhadap norma mana tidak ada norma umum yang berhubungan. Hakim diotorisasi untuk merubah hukum dalam kasus konkret. Dia memiliki kekuasaan untuk mengikat secara hukum individu yang sebelumnya secara hukum bebas.

Berdasarkan penjelasan tersebut, maka pembentukan hukum dalam kasus pengujian (toetsing) peraturan di bawah UU terhadap UUD tetap dapat dilakukan. Formulasi ini didu-kung dua asas hukum yang dapat menjadi pija-kan bagi hakim untuk menyatakan wewenang-nya menguji peraturan di bawah UU terhadap UUD. Pertama, berlakunya asas ius curia novit yang ditegaskan dalam UU Kekuasaan Kehaki-man, sebagaimana diatur pada Pasal 5 ayat (1) dan 10 ayat (1) UU No. 48 Tahun 2009 tentang Kekuasaan Kehakiman. Kedua, berlakunya asas keaktifan hakim (actieve rechterdominus litis) sebagai konsekuensi berlakunya hukum publik dalam masalah judicial review. Hal ini berimplikasi bahwa hakim karena jabatannya dapat melengkapi sendiri dasar pengujian (toetsinggronden) selain yang dikemukakan para pihak. Berdasarkan dua landasan ini hakim dapat menjadi pembuat hukum daripada penemu hukum.
Hukum dapat dikatakan terdiri dari dua bagian. Hukum legislatif dan judge made law. Berdasarkan landasan tersebut, tidak ada alasan apapun bagi hakim untuk menolak gugatan pengujian peraturan di bawah UU terhadap UUD. Konstruksi hukum ini mengakibatkan konsepsi tentang kekosongan hukum dalam pengujian peraturan di bawah UU terhadap UUD tidak perlu terjadi. Tugas pokok hukum adalah menciptakan ketertiban. Ketertiban merupakan syarat pokok adanya masyarakat yang teratur. Kepastian hu-kum harus diupayakan, agar tercapai ketertiban dalam masyarakat. Kepastian disini harus diartikan sebagai kepastian hukum dan kepastian oleh karena hukum.

Kepentingan untuk mencari keadilan itu direpresentasikan dalam batasan mencegah pembatasan hak-hak warganegara. Penyelamatan hak warga-negara dalam mencari keadilan adalah kewajiban negara yang bersifat universal. Kewajiban ini bersifat tetap dalam ramburambu yang diperbolehkan konstitusi. Oleh karena itu, selayaknya tidak ada satupun negara yang tidak memiliki peraturan tentang bagaimana negara menyelamatkan dan melindungi hak asasi warganegaranya. Hak asasi merupakan tata nilai yang ada dalam semua aspek kehidupan manusia, baik politik, hukum, ekonomi, sosial maupun budaya, termasuk dalam bidang ilmu pengetahuan dan teknologi, kesehatan, pendidikan, lingkungan dan berbagai aspek kehidupan yang lain. ${ }^{13}$ Konstitusi sendiri memiliki fungsi sebagai pengawal demokrasi (the guardian of the democracy by protecting minority rights), pelindung hak konstitusional warga negara (the protector of the citizen's constitutional rights) serta pelindung hak asasi manusia (the protector of human rights).

Konstruksi hukum pengujian peraturan di bawah UU terhadap UUD dapat dilakukan dengan landasan dua argumentasi di atas, pertanyaan selanjutnya adalah kemana permohonan pengujian dapat diajukan? Ini merupakan kon-

\footnotetext{
13 Hesti Armiwulan, "Hak Asasi Manusia dan Hukum", Jurnal Yustika Vol. 7 No. 2, Desember 2004, hlm. 323; lihat juga Pius S Prasetyo, "Membangun Sistem Politik Demokrasi Berlandaskan pada Konsep Dasar Liberalisme", Potensia: Jurnal Ilmu Sosial dan Ilmu Politik Vol. 9 No. 23, Tahun 1998
} 
sekuensi logis yang menyangkut kompetensi absolut pengadilan yang berwenang melakukan pengujian.

Gagasan awal pembentukan MK adalah menjaga agar konstitusi dilaksanakan secara konsekuen dan bertanggung jawab oleh setiap penyelenggara negara. Juga diimplementasikan dalam kebijakan yang sesuai dengan kehendak rakyat dan cita-cita demokrasi. Fungsi ini direfleksikan dalam lima kewenangan sebagaimana dirumuskan dalam Pasal 24 C ayat (1) UUD 1945. Selain lima kewenangan itu MK berke-wajiban pula untuk memberikan putusan atas pendapat DPR dalam dugaan pelanggaran kons-titusi presiden dan/atau wakil presiden.

Produk hukum di bawah UUD yang menjabarkan aturan dasar konstitusional adalah undang-undang yang dibuat oleh legislatif. Hirarkis, produk hukum di bawah UU merupakan dasar hukum bagi aturan yang lebih rendah dan melegitimasi tindakan yang akan dilakukan penyelenggara negara. Dalam rangka menjamin konstitusionalitas, baik aturan hukum maupun perbuatan penyelenggara negara berdasarkan UU dibentuklah MK yang salah satunya memiliki wewenang memutus pengujian UU terhadap UUD.

Tidak jelas apa pertimbangan pembedaan fungsi pengujian UU terhadap UUD, dengan pengujian peraturan di bawah UU terhadap UU yang menjadi wewenang MA. Pembedaan kewenangan tersebut menimbulkan persoalan, yaitu, inkonsistensi putusan yang mungkin bertentangan terhadap satu peraturan perundang-undangan. Hal ini terjadi apabila suatu Peraturan Pemerintah (PP) dinyatakan tidak bertentang-an dengan dengan UU oleh MA. Di lain pihak MK menyatakan undang-undang yang menjadi payung PP tersebut bertentangan dengan UUD. ${ }^{14}$ Meskipun Pasal 55 UU MK menyatakan pengu-

14 Meskipun Pasal 55 Undang-undang Mahkamah Konstitusi menyatakan bahwa, "Pengujian peraturan perundangundangan di bawah undang-undang yang sedang dilakukan Mahkamah Agung wajib dihentikan apabila undangundang yang menjadi dasar pengujian peraturan tersebut sedang dalam proses pengujian Mahkamah Konstitusi sampai ada putusan Mahkamah Konstitusi". Namun hal ini hanya berlaku jika proses pengujian dilakukan secara bersamaan. Sebab, secara praktis pertentangan keputusan tetap dapat terjadi jika pengujian dilakukan oleh Mahkamah Agung terlebih dahulu. jian peraturan perundang-undangan di bawah un-dang-undang yang sedang dilakukan MA wajib dihentikan apabila undang-undang yang menjadi dasar pengujian peraturan tersebut sedang dalam proses pengujian MK sampai ada putusan Mahkamah Konstitusi. Hal ini hanya berlaku jika proses pengujian dilakukan secara bersamaan. Praktis pertentangan keputusan tetap dapat terjadi jika pengujian dilakukan oleh MA terlebih dahulu.

Gagasan tersebut apabila ditinjau dari sisi politik hukum, tidak menunjukkan integralitas visi dan konsepsi hukum atas asas peradilan yang bersifat sederhana, cepat, dan biaya ringan. Kedua lembaga yang berwenang melakukan pengujian dipastikan memiliki standar/ tolok ukur berbeda tentang konsep hukum yang harus ditegakkan, maka idealnya pengujian peraturan dilakukan oleh satu lembaga sehingga menutup kemungkinan terjadinya inkonsistensi putusan dan menjamin ketegasan visi dan konsepsi hukum yang hendak ditegakkan. Oleh karena itu diperlukan mekanisme yang bisa menjembatani kesesuaian standar dan tolok ukur antara MA dan MK dalam pengujian agar putusannya berkesesuaian.

Kewenangan MK, secara keseluruhan berkaitan dengan konstitusionalitas, yaitu pelaksanaan ketentuan UUD dalam kehidupan berbangsa dan bernegara. Wewenang memutus pengujian konstitusionalitas UU untuk menjamin agar UU yang menjadi landasan kehidupan bangsa dan negara benar-benar merupakan pelaksanaan dan tidak bertentangan dengan UUD 1945. MK memiliki fungsi sebagai penjaga konstitusi (the guardian of the constitution). Fungsi ini membawa konsekuensi MK juga memiliki fungsi lain, yaiatu sebagai penafsir konstitusi yang bersifat final (the final interpreter of the constitution).

Berdasarkan wewenang di atas, maka MK menjadi satu-satunya lembaga negara dengan hak istimewa untuk menafsirkan konstitusi dalam pengujian seluruh peraturan yang telah diundangkan. Dengan kata lain, berpijak pada asas ius curia novit kewenangan untuk menguji peraturan di bawah UU terhadap UUD seharusnya menjadi kewenangan MK. Mahkamah Kons- 
titusi tidak dapat menolak permohonan pengujian peraturan di bawah UU terhadap UUD dengan alasan aturan hukumnya tidak jelas atau tidak ada. Justru penolakan itu menjadi tindakan inkonstutisional.

Pertanyaan selanjutnya adalah bagaimana prosedur pengujian harus dilakukan. Terhadap pertanyaan ini, terdapat dua skenario proses yang dapat muncul. Pertama, apakah permohonan pengujian dapat dilakukan dengan permohonan langsung ke MK tanpa ada sengketa langsung yang terkait dengan peraturan yang diuji. Kedua, bagaimana jika persoalan pengujian muncul sebagai dalil terdakwa dalam persidangan bahwa peraturan yang menjadi dasar tuntutan atau gugatan dianggap bertentangan dengan konstitusi? Apakah hakim (pengadilan) yang menangani perkara itu berwenang mengajukan kepada MK, sebelum perkara yang bersangkutan diputuskan? Atau, terdakwa atau tergugat sendiri yang harus mengajukan ke MK?

Persoalan prosedural ini memberi gambaran bahwa masalah substansi tentang kewenangan untuk melakukan pengujian peraturan di bawah UU terhadap UUD diperoleh penyelesaian hukumnya. Tetapi muncul persoalan hukum baru menyangkut aspek hukum formil atau hukum acaranya. Apakah pengadilan dapat menjadi pihak yang mengajukan permohonan judicial review? Ataukah harus orang atau badan hukum yang dapat menjadi pihak dalam sengketa tersebut?

Orientasi akhir pembentukan dasar hukum yang tuntas tentang kewenangan MK dan prosedur dalam beracara ini akhirnya harus berpijak pada asumsi bahwa hukum harus diletakan pada kepentingan hak asasi warga negara dalam mengakses hukum seluas-luasnya. Terkait politik hukum judicial review oleh MK, maka sangat tepat bila pengaturan kewenangannya tidak dirumuskan terlalu limitatif dalam UUD, sehing-ga terdapat keleluasaan bagi UU organik untuk melengkapinya. Ini mengingat bahwa perubahan UUD tidak dapat dilakukan secara mudah seperti UU biasa. Maka politik hukum menyeluruh dalam penyusunan awal UU yang mengatur kewenangan MK menjadi sangat penting.

\section{Penutup}

Analisis pembentukan MK sebagai perwujudan semangat reformasi dan supremasi konstitusi (supreme of constitution) belum mencerminkan integralitas visi hukum dalam pengujian peraturan perundang-undangan yang harus ditegakkan. Perlu dilakukan pendekatan lebih menyeluruh. Antara lain pendekatan politik hukum yang dapat mengarahkan pada kebijakan pembentukan hukum yang berpijak pada perlindungan hak asasi warganegara dan kepastian hukum pencari keadilan dalam kaitannya dengan kewenangan pengujian materiil (judicial review). Beberapa aspek yang penting diper-hatikan dalam kaitan dengan pendekatan politik hukum ini adalah pengujian oleh MK terhadap peraturan di bawah UU terhadap UUD, serta integralitas mekanisme standar dan tolok ukur pengujian antara MA dan MK agar putusanya bersesuaian.

Kewenangan memutus untuk pengujian konstitusionalitas peraturan harus menjamin bahwa UU yang menjadi landasan kehidupan bernegara harus benar-benar pelaksanaan yang tidak bertentangan dengan UUD 1945. Persoalan hukum ini meletakkan norma yang mengatur kewenangan MK menjadi sangat penting. Politik hukum dalam pembentukan UU terhadap kewenangan MK harus mampu diletakan pada kepentingan hak asasi warga negara. Politik hukum tersebut wajib berpijak pada asas pengakuan, jaminan, perlindungan, dan kepastian hukum yang adil dan perlakuan yang sama di depan hukum.

Kebijakan judicial review oleh MK dalam UUD 1945 melalui kewenangan uji konstitusionalitas, ditinjau dari sisi politik hukum, terlalu limitatif. Akibatnya tidak ada keleluasaan bagi pembentuk UU organik untuk mengeksplorasi kewenangan yang antisipatif terhadap persoalan konkrit. Kondisi ini menjadi lebih sulit, apabila para hakim masih berpijak pada pemikiran legalistik formal dan tidak berorientasi pada penemuan dan pembentukan hukum baru dalam proses peradilannya. 


\section{Daftar Pustaka}

Alfiannor, Imam. "Konsep Hak Asasi Manusia dan Implikasi Penegakkannya di Indonesia". Syariah: Jurnal Ilmu Hukum. Vol. 8 No. 1. Juni 2008. Surakarta: LPPM UMS;

Alkostar, Artidjo. “Prospek Hak Asasi Manusia Abad XXI". Jurnal Inovasi. No. 1 Tahun IX/2009. Yogyakarta: Universitas Muhammadiyah;

Armiwulan, Hesti. "Hak Asasi Manusia dan Hukum". Jurnal Yustika Vol. 7 No. 2. Desember 2004. Surabaya: FH UBAYA;

Ashiddiqie, Jimly. 2006. "Pembangunan Hukum dan Penegakan Hukum Di Indonesia”. Makalah. Lustrum XI. Yogyakarta: FH UGM. 17 Februari 2006;

Asnawi, Eddy "Relevansi Politik Hukum dan Strategi Pembangunan Hukum Dalam Rangka Menuju Sistem Hukum Nasional". Jurnal Hukum Respublika. Vol. 3 No. 1. Tahun 2003. Pekanbaru: Universitas Lancang Kuning;

Clapp, James E. 1996. Random House Webster's Pocket Legal Dictionary. New York: Random House Reference;

Hasibuan, Albert. "Politik Hak Asasi Manusia (HAM) dan UUD 1945”, Law Review Vol 8
No. 1 Juli 2008. Jakarta: Universitas Pelita Harapan;

Prasetyo, Pius S. “Membangun Sistem Politik Demokrasi Berlandaskan pada Konsep Dasar Liberalisme". Potensia: Jurnal Ilmu Sosial dan Ilmu Politik Vol. 9 No. 23. Tahun 1998. Yogyakarta: FISIP UGM;

Sudi, Fahmi. "Menuju Keseimbangan Hubungan antar Legislatif dan eksekutif". Jurnal Hukum Respublica Vol. 2 No. 4. Tahun 2003. Pekanbaru: Universitas Lancang Kuning;

Supriyanto, Hadi. "Pemisahan Fungsi Kekuasaan Eksekutif dan yudikatif". Jurnal Legislasi Indonesia, Vol. 1 No. 1 Juli 2004. Jakarta: DEPKUMHAM RI;

Syaukani, Imam. "Kareakteristik Politik Hukum Nasional”. Harmoni: Jurnal Multikultural Multireligius Vol. 7 No. 8 Tahun 2008;

Wignjosoebroto, Soetandyo. Hukum, Paradigma, Metode dan Masalahnya. 2003. Jakarta: Elsam Huma;

Yahya. "Perancangan Undang-undang Sebagai Suatu Sintesis Politik dan Hukum". Ijtihad: Jurnal Wacana Hukum Islam dan Kemanusiaan. Vol. 8 No. 1. Juni 2008. Salatiga: STAIN. 